ASSOCIATION OF WEDICAL OFFICERS OF ASTLUMS AND HOSPITALS FOR THE IITSANE.

Office Bearers and Committee of Management, 1861-2.

President-Dr. Lalor, M.S., Richmond Dis. Asy., Dublin. President Elect-Dr. Kirkman, M.S. Co. Asy., Suffolk. Ex-President - Dr. Bucknill, M.S. Co. Asy., Devon. Treasurer-WM. LEY, Esq., M.S. Co. Asy., Oxfordshire.

Auditors-J. P. Symes, Esq., Co. Asy., Wilts; Dr. Fryns, M.S., Dis. Asy., Clonmel.

Lion. Sec. (General)-Dr. L. Robrrtson, M.S. Co. Asy., Sussex (Hay ward's Heath)

Hon. Secretary for Ireland-Dr. STEWA AT, M.S. District Asy., Belfast.

Hon. Secretary for Scotland-Dr. Rorie, M.S. Roy. Asy., Dundee. Editor of Journal-Dr. Bucknill, M.S. Co. Asy., Devon.

Other Members of Commitlee.

Dr. Burton, M.S. Dis. Asy., Maryborough. | Dr. Pavl, Camberwell Ho., London.

Dr. DaveY, Northwoods, Bristol.

Dr. Thurnam, M.S. Co. Asy., Wilts.
Dr.

Dr. Gilchrist, M.S. Chrichton Instit., Dr. Harrington Tuke, Chiswick.

Dumfries.

Other Members of the Association.

Adams, Richard, Esq., M.S. Cornwall Duncan, Dr., Farnham House, Finglass. Co. Asy., Bodmin.

Artxis, Dr., M.S. Co. Asy., Inverness.

Allen, Thos., Esq., M.S. Warneford Asy., Oxford.

Arlidge, Dr., Kensington.

Armstrong, Dr., Peckham Ho., London.

Ba kewelt, Dr., Church Stretton, Salop.

Bartlett, J., Esq.

Berkeley, Dr., M.S. Distr. Asy., Mullingar.

Biggs, Dr., Co. Asy., Wandsworth.

Birketr, G., Esq., Northumberland Ho., Stoke Newington.

Brandford, Dr., Blacklands, Chelsea.

Blount, Dr., Bagshot, Surrey.

Bursragon, Dr., Duddeston Hall, Birmingham.

BoY D, Dr., M.S. Co. Asy., Somerset.

Browne, H., Esq., Haves, Middlesex.

Browne, Dr., Sussex Co. Asy., Hayward's Heath.

Brushfield, Dr., M.S.Co. Asy., Chester.

Bryan, Dr., E., Brighton.

Buck, J., Esq., M.J. Co. Asy., Leicester. Buls, Dr., Cork.

Burnet, Dr. Westbroke Ho., Alton, Hants.

Bush, J., Esq., Clapham Retreat, London.

Bushnan, Dr.S., Laverstock Ho.,Salisbury. Campbele, Dr., M.S. Co. Asy., Brentwood.

Casson, F. W., Esq., M.S. Hull Boro' Asy.

Chevallier, Dr., The Grove, Ipswich.

Chawner, Dr., V. P. Lincoln Hospital for the Insane.

Christie, Dr., Pembrnke Ho., Hackney. Cueaton, J., Esq., M.S. Co. Asy., Wakefield Conoler, Dr., D.C.L., Hanwell.

Corber, Dr., M.S. State Asy., Dundrum.

Cornwale, J., Esq., Fairford,Glo'stershire.

Corsellis, Dr., Brighton.

Daniel, Dr.

Dartngle, Dr., Arden House, Henley-inArden.

Delany, Dr., M.S. Dist. Asy., Kilkenny. Diamond, Dr., Twickenham.

Duncan, Dr., Colchester.

Duncan, Dr. Nugent, Finglas.

Eaton, Dr., District Asy., Ballinasloe.

Eccleston, T., Esq.

Eustace, Dr. John, jun., Glasnevin, co. Dublin.

Fairless, Dr., Asy., Montrose.

Fayrer, Dr., Henley-in-Arden.

Footr, Dr., Constantinople.

Fox, Dr. Francrs, \}Brislington House, Fox, Dr. Chardes, $\}$ Bristul.

Garbutr, J. M., Esq., Dunston Lodge Gateshead.

Green, Thomas, Esq., M.S. Boro. Asy. Birmingham.

Hammond, F. Esq., Co. Asy., Hants.

Hastings, Sir Crarles, D.C.L., Worcester.

Hes.ps, Dr., Royal Bethlem Hospital.

Hewson, Dr., M. S. Coton Hill Asy., Stafford.

HrLx, R. G., Esq., Shillingthorpe Hali, Stamford.

Hicls, Dr. W. C., M.S. Co. Asy., Norfolk.

Hгтсн, Dr., Sandywell Park, Glo'stershire,

Hitcucock, C., Esq., Market Lavington. Wilts.

Hitchman, Dr., M.S. Co. Asv., Derby.

Hobart, Dr. S., V. Surg., District Asy., Cork.

Hoon, Dr., Resident Phrsician, Bethlem.

Huмрнит, J., Esq., M.S. Bucks Co. Asy., Aylesbury.

Hunt, Dr., Co. Asy., Worcester.

ILES, A., Esq., Cirencester, Glo'stershire.

Jamieson, Dr., Roy. Asy., Aberdeen.

Jepson, Dr. Octavius, Co. Asy., Hanwell.

Jonks, G. T., Esq., M.S. Co._Asy., Denbigh, North Wales.

Kirkyan, Dr. W.P., M.S. Co. Asy., Carlisle.

Kitching, Dr., M.S. Retreat, York.

KNight, Dr., V.P. Co. Asy., Stafford.

Diamond, Dr. W. H., Effra Hall, Brixton. Law, Dr. R., V.P. Central Asy., Dublin.

Drckson, Dr., Wye House, Buxton. Lawlor, Dr., M.S. Killarney Distr. Asy.

Dixon, Dr. F. B., Hoxton House, $\mathrm{N}$.

Down, Dr. LANGDon, Idiot Asy., Red Hill.

LAW LoR, Dr., M.S. Killarney Distr. Asy. bridge.

Durfy, Dr., Finglass, Dublin. $\quad$ Lew18, H., Esq., 54, Paradise St., Lambeth.

Dukr, Dr., Dublin.

Livdsay, Dr. J. M., Royal Asylum, Perth. 


\section{List of Members-continued.}

Lorimer, Dr., Crumpsall New Workhouse, Manchester.

Low e, Dr., Saughton Hall, Edinburgh.

Low rY, Dr., West Malling, Kent.

Lynch, DR., Drumcondra.

Mackintosh, Dr., Dimsdale Park, Darlington.

Mackintosh, Dr., M.S. R. Asy., Glasgow.

Mackintosh, DR. W. C., Royal Asylum, Perth.

Macmuns, Dr., Dist. Asy., Sligo.

Madden, Dr., Asy., Somerset.

Manley, Dr., M.S. Co. Asy., Hants.

Marshall, W. G., Esq., M.S. Co. Asy., Colney Hatch.

MaudsLey, Dr., Cheadle, Manchester.

M‘Cullough, Dr., M.S., Co. Asy., Abergavenny.

McKinstry, Dr., Armagh Dis. Hos.

MeYer, Dr., M.S. Surrey Co. Asy., Wandsworth.

Millar, J. N., Esq., Bethnal Green Asy.

Miller, Dr., V.P. St. Thomas Hos., Exeter.

Mosro, Dr. H., Cavendish Square, V.P. St. Luke's, London.

Morison, Sir Alexander, M.D., Pembridge Gardens, Notting Hill.

Moss, Dr. W. C., Longwood Ho., Bristol.

Muirhzad. Dr., Longdales Asy., Bothwell

Nédнam, E., Esq., Lunatic Hos., York.

Newington, Dr. Charles Hayes, Ticehurst, Sussex.

Newington, Dr. Sayozc, Ridgway, Ticehurst, Sussex.

Nivre, Dr., H.E.I.C.S. Med. Depart., Bombay, late Co. Asy., Essex.

Noble, Dr., Manchester.

Oliver, Dr., M.S. Co. Asy., Shropshire.

Palmer, Dr., M.S. Co. Asy., Lincolnshire

Paley, Dr. E., 39, Arlington Street,

Mornington Crescent.

Parsey, Dr., M.S. Co. Asy., Warwickshire.

Phinlips, E. P., Esq., M.S. Co. Asy., Haverford West.

Philp, Dr., late V.P. St. Luke's.

Power, Dr., M.S. District Asy., Cork.

Prichard, Dr., Abington Abbey, Northampton.

Raz, Dr., Naval Asy., Haslar.

Robinson, Dr., Newcastle-on-Tyne.

Rog^n, Dr., M.S. Londonderry Dist. Asy.

Rogers, Dr., M.S. Co. Asy., Rainhill.

Ross, Dr. A., Waterloo, near Portsmouth.
Sanrex, H., Esq., Co. Asy., Oxford.

SANEeY, Dr., M.S. Co. Asy., Hanwell.

Saunders, J., Esq.. Co. Asy., Devon.

Sreppard, Dr. E., M.S. Co. Asy., Colney Hatch.

Sherlock, Dr., M.S. Co. Asy., Worcester.

Sibanld, Dr., Roy. Asy., Edinburgh.

Srae, Dr., M.S. Royal Edinburgh Asy.

Syrth, Dr. F. M., Hadham Palace, Herts.

Sxrт,, Dr. G. P., Mount Stead, Ilkley.

Smite, Dr. R., M.S. Co. Asy., Durham.

Smitr, Dr. Jno. 20, Charlotte Square, Edinburgh.

Stanley, W. S., Esq., Rathfarnham, co Dublin.

Stevens, Dr. H., Grosvenor Street, London.

Srephens, Dr., H.O., Borough Asy., Stapleton, Bristol.

Strwakt, Dr. H. H., M.S. Govt. Asy. Lucan, co. Dublin.

Stirf, Dr., M.S. Co. Asy., Nottingham.

Stilweld, Dr., Morcroft House, Uxbridge. Sutrersand, Dr., Richmond Terrace, Whitehall, C.P. St. Luke's, London.

Syres, J. G., Bsq., M.S. Co. Asy., Dorset. TAre, Dr., Lunatic Hospital, Nottingham. Trere, J., Esq., Bailbrook House, Bath,

Toller, E. Esq., M.S. St. Luke's Hospital, London.

Tuke, Dr. Daniel H., Falmouth.

Tyerman, F. D., Esq.

W Alsh, F. D., Esq., M.S. Hospital for the

Insane, Lincoln.

W Arson, J. F., Esq., Heigham Hall, Norwich.

WARwice, J., Bsq.

West, Dr., M.S. District Asy., Omagh.

WeItz, Dr., V.P. Dist. Asy., Derry.

Willetr, Dr., Wyke House, Brentford.

Williams, Dr. Caleb, York.

Williams, Dr., M.s. Co. Asy., Gloucester.

WILson, R., Esq., M.S. Northumberland Co. Asylum, Morpeth.

Wictox, F., Esq., Co. Asy., Gloncester.

Wrse, Dr., M.S. Gen. Lun. Hos., North. ampton.

Wood, Dr., Harley Street, Cavendish. Square.

Wood, Dr. A., Barnwood Ho. Asy., near Gloucester.

Wynter, Dr. Andrew, Coleherne Court, Old Brompton.

\section{Honorary Members.}

Baiclarger, Dr., La Salpêtrière, Paris.

Battel, M., Paris.

Boismont, Dr. Brierre de, Paris.

Hatcheld, Dr., Inspector of Asy., Ireland How e, Dr., Boston, U.S.

Holland, Sir Henry, Bart., M.D.

Brow ve, Dr., Com. in Lun. for Scotland. Jarvis, Dr., Boston, U.S.

Brodie, Sir Benjamin Collins, Bart. D.C.L.

Calmeil, Dr., Charenton, Paris.

Coxe, Dr., Commissioner in Lunacy for Scotland.

Falret, Dr., La Salpêtrière, Paris.

Lay cock, Professor, Edinburgh.

Morel, Dr., St. Yon, Rouen.

Natrne, Dr., Commissioner in Lunacy.

NugeNT, Dr., Inspector of Asy., Ireland.

Peach, Dr., Langley Hall, Derby.

RAY, Dr., Boston, U.S.

Flemming, Dr., Editor of the 'Zeitschrift der Psychiatrie.'

Gasrele, S., Esq., Commissr. in Lunacy.
Stanley, Hans Sloanr, Esq., Chairman of Visiting Magistrates, Hants Co. Asy.

Wilres, J., Esq., Commissioner in Lunacy. 
SOCIAL SCIENCE REVIEW, No. 2, ready on JUNE 21. Costents - Hospital Ahuses. - Education in New South Wales.- Pemale Physicians. - Falsifications of Money. - Proceedings of the Congres International de Bienfaisance; Complete Report. - Hroceedings of the National Association of Social Science.-Illegitimacy in Scotland.-Zoology and Public Health, - The Day.

Office - 10, Wuirkmanas' Strake, R.C. Price 3d. Stamped 4d.

\section{HEALTH, FRESH AIR, AND PURE WATER. CONDY'S HYGIENIC PREPARATIONS, BY HER MAJESTY'S LETTERS. COIDY'S FLUID,}

Which contains noseent Oxygen, Nature's true and owly merifying agent, instantly destroys all offensive smells, remuves organic impurities from water aud air, and, being entirely innoxious and unirritatinz in its nature, is the only safe disinfectant of the living tissues, whether for external application or for consuming and counteracting organic poisons taken into the stomach, or generated in the system. "I consider it io be a most important addition to wanitary science, and a valuable agent in the hands of the medical profession."-Rosert DuNDas Thomson, M.D., F.R.S.

\section{CONDY'S PATEIT FLUID,}

By reason of its peruliar compnsition, is invaluable as a preventive and cure for the diseases of domestic animals, which are so liable to assume a contagious 1ype. "I con. sider Condy's finid. in short, a boon to the veterinary profession and the sportsman, as well at to the community at large."-W.H. KENT, M.R.C.V.S. "Il appears to me to be a most valuable and healthy life preserver."-F. T. BuckLnND, Ass.-Surg., 2d Life Guards. In Bottles, Green, 6d, 1s., and 2s. Crimson, stronger and purer, 1s., 2s., and 40.

\section{CONDYS PATENT HEATIH POWDER,}

Also containg nascent oxygen, is odourless, and destroys all smells. Sold in Bottles, 1.., 1.. $6 d$., and 3s; ; and in casks, 1 cwt., 36 s.

\section{CONDY'S PATEHT OZONTSED WATER,}

For the toilet, bath, \&c., removes from the mouth impure and foreign tastes and odours, whether arising from tohacco or other causes, and counteracts the irritation and morbid secretions of carious teeth. It purifies and softens the skin, and, used in the bath, tends to promote a healtiyy state of the whole body. "A teaspoonful added to a tumbler of water will remove instantaneoutly all the taste and smell which are often so troublesome, afler smoking pipes or cigars."-The Field, November 24th, 1860. In stuppered Bottles, price $2 s . ;$ double size, 3s. $6 d$.

Liq. Potass. v. Calc. v. Magnes. Permangan (Condy), gr. ij ad $\mathbf{3 j}$.

Solutions of absolutely pure salts of permanganic acid, prepared of uniform strength for preseription by nedical men.

Internally - Dose from ten drops to a drachm in half a pint of pure water.

Externally-As a lotion or gargle, frow one to four dirachms in half a pint of pure water.

\section{PRITCIPAT WHOLESATB AGKATS.}

J. Bzt.t and Co., 338, Oxfurd Street. Butler, Sarkville Street, Dublin.

J. Rohertson and Co., Bdinhurgh.

Davies, Jameson, and Co., Bath.

Passmore and Sons, Bxeter.

Grattan and $\mathrm{Co}$., Belfast.

T. Standrung, Mauchester.

Butterfield, Clarke, and Co., York.

Harrey and Reyuolds, Leeds.
H. B. Brady, Newcastle. Ferris, Townsend, and Co., Dristol.

Heruer and Sutton, Norwich.

Clay. Dool, and Case, Liverpool.

Randall and Son, Southampton.

Cornish and Lewin, Plymouti.

Glaisyer and Kemp, Bitghton.

J. and W. Sumner, Birmingham.

Twisberrow, ant Co., Woreester. 
Second Edilion, Enlarged, 8vo, eloth, 15 .

A MANUAL OF PSYCHOLOGICAL MEDICINE : containing the History, Nosology, Description, Statistica, Diagnosis, Pathologr, and Treatment of Insanity; with an Appendix of Cases. By JOHN CIIRLES BUCKNILL, M.D., Medical Superintendent of the Devon County Lunatic Asylum ; and DANIEL H. TUKE, M.D., late Visiting Medical Oficer to the York Retreat.

"Certainly the best work on Psychologienl Medicine lately written in Europe."' Essay on Moral Insanity', hy Dr. Parigot, late Commissioner in Lunacy, Belgium. 1861. JOIIN CHURCHILI, New Burlington Street.

Now Ready, 8vo, cloth, 58.

INFANTICIDE : its LAW, PREVALENCE, PREVENTION, AND HISTORY. BY WILLIAM BURKE RYAN, M.D. I.ond, F.R.C.S. Eng.

"The sulject is of greal importance, and Lord Brougham recommenda Dr. Ryan to send a full statement of the facts and of his suggestions to the Meeting of the National Association for the Promotion of Social Science."

JOHN CHURCHILL, New Burlington Street.

Third Edition (incorporating the Gulstonian Lectures delivered at the Royal College of Physicians), post 8vo, cloth, 7s. $6 d$.

ON EPILEPTIC AND OTHER CONVULSIVE AFFECTIONS OF THE NERVOUS SYSTEM. By CHARLES BLAND RAD. CLIFFE, M.D., F.R.C.P., Physician to, and Lecturer on Matcria Medica and Therapeutics at, the Westminster Hospital.

JOHN CHURCHILL, New Burlington Street.

Third Edition, entively Re-veritten, 8vo, cloth, $10 \mathrm{~s} 6$ 6.

THE FUNCTIONS AND DISORDERS OF THE REPRODUCTIVE ORGANS IN CHILDHOOD, YOUTH, ADULT AGE, AND ADVANCED LIFE ; considered in their Physiological, Social, and Moral Relations. By WILLIAM ACION, M.R.C.S., formerly Exterue to the Female Venereal Hospitals in Paris.

"Everywhere we may see that the author has thought deeply, observed largely, and means honestly." - The Lancet.

"We willingly indorse Mr. Acton's opinion, that the evils which environ the abuses of the sexual instinct demand plain teacling and open investigation. He discusses with the freedom of a philosopher the efficacy of modern systems of religion and education in promoting chastity."-Med. Times.

JOHN CHURCHILL, New Burlington Street,

SPARKS AND SON, INVENTORS of the INDIA-RUBBER URINALS for MALE and FEMALE RAILWAY TRAVELLERS, INVALIDS, and CHILDREN.

These Urinals are made on the most approved principles, and all are fitted with the recently-invented valve, which will not allow any return of the water by the upper part, by lyeing placed in any position, and from their improved construction are better than any similar articles at present in use.

A liberal discount to the Medical Profession. Deseriptive Circulars and Lists of Prices sent per Post.

Hospitals, Infirmaries, and Unions supplied on the best terms with every article for the use of the sick and invalided. SPARKS AND SON,

Patrnt Surgtonl Tauss and Bandage Marerg,

28, CONDUIT STREBT, NBW BOND STREET, LONDON. Bstabliseze aBove 30 Yeants. 


\section{PULVIS JACOBI VER., NEWBERY'S.}

To the Medical Profeffion of Great Britain and Ireland.

CI

ENTLEMEN, - We beg to call your attention to the following extracts

from a Paper by the late John Cheyne, M.D., F.R.S.E., M.R.I.A.,

Phyfician to the Hardwicke Fever Hofpital, Dublin, and Phyfician-

General to His late Majefty's Forces in Ireland, \&c., \&c., contained in the

"Dublin Ho/pital Reports," vol. 1, p. 317.

"Since this cafe came into my pottellion, 1 have been led to make a good many clinical "experiments, which have enabled me to verify the reports which I had heard of the efficacy " of JAMES'S POWDER, in fomerimes temoving the APOPLECIIC DIATHE:IS in perfuns "advanced in life, It is, moreover, son"ly of obfcrvation, that IAMEe"s POWDER has

" been of remarkable utility in certain inftances of DrTrtimisation of BLOOD TO THE HEAD,

" which occurred at an early period of life, and threatened to end by effufion. Laftly, in two

" cafes of GENERAL TLETHORA, in which, however, the head was more affected than any other

"part, JAMES'S POWDER wat cathbited by me with perfect fuccefss."

Alfo vol. $1, p .320$.

"The following very fimple method of exhibiting JAMES'S POWDER, in cafes of undue " determination of blood to the head, is that which 1 have generally purfued. The patient is " made to begin with a very moderate dofe, not more than two grains at bedtime, and to increafe

" the dofe by half-a-grain every night, until forne fenfble oifect is produced upon the ftomach,

" bowels, or $\mathrm{fkin}$. Should the nomach be sffected with fickress, the dofe muft be lefiened by " one grain on the following night. By the aiticion of a little rhubarb to it, a larger quantity

" of JAMES'S POWDER may be adminiftered than the flomach could otherwife bear. If

" the fkin is foftened, or thie bowels affected, the dofe flould not further be increafed, but it

" muft be repeated every night for a confidereble length of time : in feveral infances $I$ have

" known eighiteen or fwecnty grains taken for a confiderable period quitbout any inconvenicnce."

The following extract (fhowing the increafing eftimation in which the true Dr. James's Powder is held by Medical Practitioners) is taken from "The Lumlean Leêures," 18,58-59, delivered before the Royal College of Phyficians, by A. Tweedie, M.D., Phyfician to the London Fever Hofpital, who is admittedly one of the higheft pro lical authorities on the fubject of Fever. He faid, ("The Lancut," June I6, 1860, p. 590,) as follows:-

"If the febrile excitement be fuch as to require antimonial preparations, a pill containing 2 " or 3 grains of James's Powder (prepared by Newbery) thould be taken at intervals according " to circumftances."

In writing to Meffrs. Newbery, he made the following ftatement:-

"I wifh that your preparation was always ufed."

To fecure the difpenfing of the original preparation, which, for 114 years, has been fold by the houfe of Newbery and Sons, in St. Paul's Churchyard, it is neceffary to preferibe it as "PULVIS JACOBI VER., NEWBERY'S," otherwife another article (wanting in the beft properties, and recommended to be given in a different code of dofe, tbougb called by the fame name) may be fubftituted for the original medicine.

This fubftitution muft bring difappointment, and of courfe deter Practitioners from prefcribing Dr. James's Powder, or lead them to regard it as a preparation on which no dependence can be placed.

45, St. Paul's Cburcbyard, London.

FRANCIS NEWBERY AND SONS.

Prices for Difpenfing $\frac{1}{4}$ oz. Bottle, 3 s. 4 d.; 1 oz. gs. Ufual Difcount

PLEASE TO PRESCRIBE IT As

PULVIS JACOBI VER., NEWBERY'S. 